\title{
A Frankfurt School Reading of Samuel Beckett's Trilogy as a Literary Solution to Modern Man's Problems
}

\author{
Dr. Hossein Sabouri ${ }^{1}$, Dr. Firouzeh Ameri ${ }^{2}$, Sobhan Jahangiri ${ }^{3 *}$ \\ ${ }^{1,2}$ Associate Professor, Department of English, University of Tabriz \\ ${ }^{3 *}$ M.A. Student of English Literature, University of Tabriz \\ 29 Bahman Blvd, Tabriz, East Azerbaijan, Iran
}

\begin{abstract}
In terms of literature, and especially the genre of novel, the modern man's problems could be identified as alienation, identity crisis, partial understanding of characters, complexity of language, misunderstanding of narrative techniques, non-applicability of criticism and other facets. One of the movements which tackled a great deal of complicated philosophical-literary discussions is Frankfurt School. However, the discussions have been based on negation, in a way that one of the greatest works of the school, Negative Dialectics (1973), is based on the 'negative' understanding of 'synthesis' theory, which convinced many scholars to believe that the school actually has no solution at all, but mainly asserting on negation. In line with the School, Samuel Beckett, one of the greatest literary figures, considers the problems of modern world and modern human in order to create a solution for that. The present article intends to show that aside from his plays, Beckett depicts a new language, new form, new idea, and a different narrative in his works, especially in his trilogy, and therefore a real solution to the modern era.
\end{abstract}

Keywords: Beckett, the Trilogy, Frankfurt School, Modern Man's Problems, Literary Solution.

\section{INTRODUCTION}

Modern man's problems are some of the important questions with which human beings have long been dealing. The struggle has made many literary and non-literary figures to offer solutions to the problems. They include a gamut from meta-narrative and meta-methodological notions to minor psychological and political paradoxes. Although Beckett's trilogy has received a great deal of attention by many thinkers and movements, especially postmodernists, a Frankfurtian reading of Beckett's trilogy has not thoroughly been applied yet. Many studies have attempted to apply mere theories to the trilogy, but none has found it a significant attempt to provide a literary solution, as powerful as philosophical movements, for the philosophical problems of modern world. The ultimate purpose of this study is to identify some of the modern man's problems according to the first generation of Frankfurt School and then attempts to find the literary solutions for these problems and questions within the trilogy of Beckett. This study would like to show how the trilogy creates new forms, identities, and narratives, as well as other literary processes, which create a new language and suggest new solutions for the problems of modern world. The study employs a descriptive-analytical method through a textual analysis and is qualitative.

There are many studies about Beckett and his works. In case of comparison, Meihuizen's "Beckett and Coetzee: alternative identities" (2011) compares Beckett to Coetzee as they share a "minibiography" in their writings. The author attempts to delineate the traces of both writers' presence in their works. Furthermore, the influence of Beckett on Coetzee is examined. The inverse relationship, i.e. the influences on Beckett, is examined in an article by Sasani and Ghasemi titled as "The influence of Anton Chekhov on Samuel Beckett" (2011). Borrowing the term "influence" from Harold Bloom, they argued how Beckett's oeuvre, specially his "Waiting for Godot", portrays the passiveness of the characters, the same as Chekhov. They indicate the similarities between "Waiting for Godot" and "Three Sisters" in terms of form, atmosphere, and theme. A more philosophical and theological comparison can be seen in Bellini's "Samuel Beckett and St. Augustine" (2015). He argues that Beckett was heavily under the influence of St. Augustine for the term "habit", which had been explained earlier in "confessions". The author chooses "Murphy" as the primary text for discussing the dialectical identity, which eliminates the veil of "habit". In "Time, Waiting, and Entrapment in 


\section{Dr. Hossein Sabouri et al.}

Samuel Beckett" (2014), Shalghin studies the "condition" of the Beckett's characters in three of his plays. She attempts to depict the limitations and status quo of the characters with their unknown past to show the "harsh reality" of their life. She concluded that the initial problems at the beginning of the plays still remain at the end. In a work titled as "Failed Quest in Samuel Beckett's How It Is" (2012) by Najafi, et al., the study argues that Beckett's "How It Is" does not follow the normal definition of novel genre. They discuss how the notion of "antihero" indicates itself in the "failure" of the characters as they fail to express themselves, although they are obliged to express themselves. They conclude that "it" in the title shows a narrator without any gender. In "The Literature of the Absurd: Writing against Death" (2013), Chesca examines the literature of absurd as the disfigured face of language and logics. She argues that the theatre indicates the tragic existence of mankind, and the works of the playwrights such as Beckett express the condition as a "labyrinth", in which "death" is a ubiquitous phenomenon within the existence. In addition, in "The Topos of the Mound in Samuel Beckett's Writing" (2013), Habibi introduce the term "mound" as a multi-faceted symbol, which is frequent in the Beckett's oeuvre. He investigates the terms "topos", "death", and "Venus" in his works symbolically. More pertinently to the present dissertation, in a study entitled as "Mental SelfExploration in Samuel Beckett's Molloy" (2015), Jamalinesari and Feilinezhad exploit a Jungian approach to one of the trilogy's novels, i.e. Molloy. They argue that the characters of Beckett are deformed and deteriorated ones, who attempt to establish a meaning in their lives and search for their true identities. The study exploits a Jungian approach to show how the characters evade identity through archetypes. Finally, "Samuel Beckett's Trilogy, Alain Badiou and the Subtraction from the State and the Community" (2013) by Lopez discusses Alain Badiou's "subset" in confronting the community, using the "critique of communitarian ethics and of the administrative and management function of the state" (32). Lopez investigates "the trilogy" and its characters as the non-conformists and the ones who are against the authority and totalitarianism.

\section{Modern Man's Problems and The Frankfurt SCHOOL}

The diverse nature of the School's theories as well as complex and complicated style of writing, made the understanding of their texts hard for researchers. As Martin Jay comments on Adorno in "Dialectical Imagination", "[t]o discuss in detail the complexities of his work in this area beyond what has already been done, let alone to analyze it critically, would be beyond my ability" (193). This explains how hard and enigmatic is the writing of the School's members. Nevertheless, there are some general and bold theories in the School that have highly influenced next generations of philosophers, socialists, and psychoanalysts. As Ross Wilson suggests in Theodor Adorno, the School's "influence on literary theory, cultural studies and philosophical aesthetics has been immense" (123), and the major theories are the milestones and benchmarks for understanding the minor theories of the Frankfurters. Talking about the modern man reminds a researcher of "one-dimensional man", who faces the psychological derives that are built within the social milieu. One aspect of the modern man is the subconscious structure based on the mechanisms of society, "even the pleasure-principle itself changes into the more accommodating reality-principle under the influence of external environment" (Freud 24). The mechanisms are mostly based on politics and social relationships as Karl Marx suggests in Capital, "[t]he structure of the fundamental economic elements of society remains untouched by the storms which blow up in the cloudy regions of politics" (479), and are shaped by the bourgeois or (higher) middle class. Plus, the whole system of society runs through the mundane objectives of the Capitalism. As the ultimate goal of the Capitalism is to produce and create more wealth or "the accumulation of wealth" (Marx 799), the "uniformity" of the individuals, towards a harmonic society, is really important. The Capitalism, through the mass media, prepares the society and the individuals to hold the "homogeneous" ideas and to have a generic sense of the structures of the society. The mass media constantly and repeatedly promulgate false needs to the individual, which is "less suitable to his needs than, perhaps, for centuries had been the case" (Marx 837). In "Minima Moralia", Adorno argues that the modern or the Capitalist society has changed the values based on "the relativism of values," and "the absence of binding norms" (211); a notion that his predecessor, Nietzsche, previously mentioned under the name of "transvaluation" or the "revaluation of all values" ("Ecce Homo" 174). He means that by building all the modern relationships based on the Capitalism, the society changes the values, and by creating new values according to pecuniary relations, not human relationships, the society shifts to an "inhuman society". "We shudder at the brutalization of life, but lacking any objectively binding morality we are forced at every step into actions and words, into calculations that are by humane standards barbaric, and even by the dubious values of good society, tactless" (Minima Moralia 27). The question is how the subject is distorted by the 
Enlightenment or the Capitalism. The answer is the "culture industry". It is the mechanical reproduction of the object that is external to the object or nature. "Institutions are more powerful than ever; they have long since produced something like the neon-lit style of the culture industry, a style that covers the world as the turn to the baroque did once upon a time" (Adorno, "Negative Dialectics" 94). It makes mass or "collective consciousness"; "a stage of social organization, that is opposed as an entity to the real process of society's production and reproduction" (Adorno, "Negative Dialectics" 340), i.e. a generic distorted consciousness. Another term that Adorno exploits in "Jargon of Authenticity" is "aura", borrowed from Benjamin. "Aura" is not a conceptual content but creates impression. "The fact that the words of the jargon sound as if they said something higher than what they mean suggests the term "aura"" (Adorno, "Jargon of Authenticity" 9). Individual is deprived of "self" to be relied on mundane rather than spiritual existence because of the empty "jargon". "Behind these empty claims for freedom the socioeconomic processes of advanced capitalist integration continue, intensifying the dependence of all persons upon large organizational units for employment and welfare" (Adorno, "Jargon of Authenticity" xv). The irony is that "powerlessness" is necessary for the "authenticity" especially submission to the external power. "[A]11 men are equal in their powerlessness, in which they possess being. Humanity becomes the most general and empty form of privilege" (Adorno, "Jargon of Authenticity" 66).

\section{LITERATURE AND THE FRANKFURT SCHOOL}

"We know that the earliest art works originated in the service of a ritual-first the magical, then the religious kind" (Benjamin 223). However, after the advent of the modern apparatuses, i.e. "mechanical reproduction", art became detached from its authority; "for the first time in world history, mechanical reproduction emancipates the work of art from its parasitical dependence on ritual" (Benjamin 224). In line with Benjamin, what Adorno means about aura in "Notes to Literature II" is that "[t]he superior power of the status quo becomes a magical aura for the world" (155). However, the autonomy of literature in view of Horkheimer and Adorno is different from Benjamin. They believed that art, under specific social conditions can provide another form of reality or distortion to the irrationality of the modern world; "[t]he distortion which is inherent in every work of art" (Horkheimer and Adorno 209).

For Adorno, literary or artwork must be without purpose; it must be "functionlessness" or "unfunctional" (Adorno, "Jargon of Authenticity" 108). However, culture industry destroyed individuality and critical thinking, as well as literature through the uniformity of the mass. Art, in this regard, is served as a medium of ideological domination. "Everything that exists is to be made identical to a life that is itself death, abstract domination" (Adorno, "Notes to literature II" 270). The procedure is in a way that monopolistic system makes a "positivist" method to control and manipulate art and literature or "taste" of individuals for more profitability. "The average empathic connoisseur, the man of taste, is now and probably always has been in danger of missing works of art by degrading them to projections of his own contingency rather than subjecting himself to their objective discipline" (Adorno, "Notes to Literature I" 100). The standard art generates standard questions and answers, which are against critical thinking. Literary works in the modern era are according to the taste of the mass or "pop". "The adjustment of reality to the masses and of the masses to reality is a process of unlimited scope, as much for thinking as for perception" (Benjamin 223). Adorno argues that art must be differed from form: "the essay has something like an aesthetic autonomy that is easily accused of being simply derived from art, although it is distinguished from art by its medium, concepts, and by its claim to a truth devoid of aesthetic semblance" (5). What he tries to say is that literature (or form) is different from essay or science, which is in contrast to the idea of Lukács. Adorno criticizes positivism because "the general positivist tendency to set every possible object, as an object of research, in stark opposition to the subject, does not go beyond the mere separation of form and content" ("Notes to Literature" I 5).

Horkheimer was seeking to answer the question and his suggestion was the "French Literature". As he was escaping the binary opposition between subject and object in his work "Eclipse of Reason", he writes "reason acquired a new connotation, which found its highest expression in French literature" (9). Marcuse, in his book "One-Dimensional Man", advocates a "free literature". "The greatness of a free literature and art", Marcuse believes, is important "in the competitive struggle between East and West" (Marcuse 60). 


\section{Dr. Hossein Sabouri et al.}

It seems that the distinction between literature and philosophy is not clear enough. "There is not 'much occasion' any more, Rorty suggests, 'to use the distinction...between philosophy and literature" "(Lansdown 55). Charles Taylor believes that the approaches of literature and philosophy are "undifferentiated". "It is the final outcome of a way of reading literature that sees Plato and the poets as simply having divergent 'views', or Sophocles' dramas expounding a 'position' relative to classical Greek thought and modern liberalism: that tends to see philosophy and literature as undifferentiated approaches to the world" (Lansdown 75). Literature, directly, can act as a social apparatus to affect the reality. Nietzsche also believes that poetry in ancient times (or literature) is inseparable from philosophy. Nietzsche suggests that "Plato really did bequeath the model of a new art-form to all posterity, the model of the novel, which can be defined as an infinitely intensified Aesopian fable where poetry has the same rank in relation to dialectic philosophy as, for centuries, philosophy had in relation to theology" ("Birth of Tragedy" 69). Walter Benjamin reveals a point about literature that can hardly be seen in any other branches of knowledge: flexibility and comprehensiveness. "It has rightly been said that all great works of literature found a genre or dissolve one-that they are, in other words, special cases" (Illuminations 201). What he explains is related to the nature of literature, not even the style of literature. He sets the inherent feature of a literary work in its "historical form". "Even words with fixed meaning can undergo a maturing process. The obvious tendency of a writer's literary style may in time wither away, only to give rise to immanent tendencies in the literary creation" (Illuminations 73).

Looking at the works of Beckett, especially his novels, one would perceive the closeness of them to the desired literature for the philosophers and literary critics. "The trilogy" is the summit of his novels, which is a never-ending treasure to explore the humanistic features of the modern world.

\section{A Literary Analysis of the Trilogy}

\subsection{Molloy}

"Molloy" is a formal story and thus the most traditional novel of "the trilogy". However, the story collapses quickly in the story into an underground and vague whisper of subjectivity. The story begins with the confinement of "Molloy" after the death of his mother. "I am in my mother's room. It's I who live there now. I don't know how I got there. Perhaps in an ambulance, certainly a vehicle of some kind. I was helped. I'd never have got there alone" ("Trilogy" 7). He just writes and a strange character collects his writings periodically and in return gives him money. "There's this man who comes every week. Perhaps I got here thanks to him. He says not. He gives me money and takes away the pages. So many pages, so much money" ("Trilogy" 7). What he has written is a start of his status quo and an explanation of his journey to find his dead mother. The story continues with his observance of two men called "A" and "C", who are approaching each other. One of them carries a "stick" and the other a "dog". "So I saw A and C going slowly towards each other, unconscious of what they were doing" ("Trilogy" 9). "Molloy" is not sure if they are travellers. They approach each other, exchange few words and then separate. Maybe the two of them remind "Molloy" that moving is possible and coax him to follow his journey and to leave his dormant life. However, his journey is not easy as one of his legs has a problem. Thus, he travels with his "bicycle" and fastens the "crutches" to the "bicycle". A "policeman" pesters him for a specific and an unknown crime. "He was eloquent. I pointed out that I was not sad. That was a mistake. Your papers, he said. I knew it a moment later. Not at all, I said, not at all. Your papers! he cried" ("Trilogy" 20-1). When he accidentally runs over a dog and kills the animal, some angry citizens attempt to kill him. "For I had hardly perfected my plan, in my head, when my bicycle ran over a dog, as subsequently appeared, and fell to the ground, an ineptness all the more unpardonable as the dog, duly leashed, was not out on the road, but in on the pavement" ("Trilogy" 32). But the dog owner who is "Mrs Loy" or "Lousse" saves him. "Lousse" takes him instead of her beloved dog and spoils him like an animal. "Molloy" escapes from her mercy and gentleness, and while running from the house owner, steals some silvers like Jean Valjean. "I had stolen from Lousse a little silver, oh nothing much, massive teaspoons for the most part, and other small objects whose utility I did not grasp, but which seemed as if they might have some value" ("Trilogy" 63). He abandons his "bike" and uses his "crutches" to walk. His cripple leg hurts him much more, so he rests for a few days in a cave near a beach. "And in the morning, in my cave, and even sometimes at night, when the storm raged, I felt reasonably secure from the elements and mankind" ("Trilogy 75). As moving becomes harder day by day he reaches a "charcoal burner" in the "woods" and "Molloy" beats him to almost death. After the event, he cannot walk vertically anymore, so he creeps to pass the woods. "Christ, there's crawling, I never thought of that. But could I crawl, 
with my legs in such a state, and my trunk? And my head" ("Trilogy" 89). At least four seasons have passed since the start of his journey and it is spring again. "It must have been spring, a morning in spring. I thought I heard birds, skylarks perhaps" ("Trilogy" 91). At the edge of the woods, he notices "plains", "towns" and "villages". "It is true the plain seemed familiar, but in my region all the plains looked alike, when you knew one you knew them all" ("Trilogy" 90-1). He is not certain if he can pass the "plains" that he suddenly hears a voice, which ends the first part of the novel. The second part of the novel is the story of "Moran", who unlike "Molloy" is determined, tactful, and logical, but acts based on habits. He is a bigot and observes the household and religious rituals carefully, and has made his "son" obedient. He is afflicted with paranoid and his pleasures are confined to the fretful frame of bourgeois rituals. His only interest is his "bees". "The weather was fine. I watched absently the coming and going of my bees" ("Trilogy" 93). "Moran" is a private detective, who works for "Youdi" and the orders are delivered to "Moran" by a messenger called "Gaber". "Here are your instructions, said Gaber. He took a notebook from his pocket and began to read" ("Trilogy" 94). One day "Gaber" delivers an order to "Moran", which states that Moran must follow "Molloy" forthwith. "Gaber" does not explain and "Moran" does not ask. "I neither got up nor invited him to sit down. He stopped in front of me and we stared at each other in silence "("Trilogy" 94). "Moran", like "Molloy" starts his journey, but he takes his "son", "Jacques". "My son had a way of saying papa, when he wanted to hurt me, that was very special. Now listen to me, I said. His face took on an expression of anguished attention. We leave this evening, I said in substance, on a journey" ("Trilogy" 103). The journey has a negative effect on him and worsens his psychic condition. For some moments, he changes to be his author, Beckett:

Oh the stories I could tell you if I were easy. What a rabble in my head, what a gallery of moribunds. Murphy, Watt, Yerk, Mercier and all the others. I would never have believed that yes, I believe it willingly. Stories, stories. I have not been able to tell them. I shall not be able to tell this one. ("Trilogy" 138)

He becomes crippled just like "Molloy" and has to crawl. In the woods he sees two men, kills one of them and hides the body in the forest. "I dragged him into the copse, with frequent rests on the way, but without letting go his legs, so as not to have to stoop again to pick them up. Then I dismantled the shelter and threw the branches over the body" ("Trilogy" 152). He sends his son to buy a "bicycle"; therefore, "Jacques" rides the "bicycle" and he clings to the "bicycle" bags. Finally, his son abandons him and "Gaber" appears with new orders. "He came and bent over me. He had a walrus moustache, chestnut in colour. I saw it lift, the lips open, and almost at the same time I heard words of solicitude, at a great distance" ("Trilogy" 165). In his way back home, "Moran" asks theological questions to soothe his mind. When he finally reaches the house, he finds out that his house is destroyed, and his "bees" are dead. "I knew they were dead" ("Trilogy 175"). There is a voice in his head and, like "Molloy", he has to write. As it can be understood, the two protagonists of the novel are so similar. The whole story could be figured out as a parody or a game using theological names like "Youdi". It seems that the novel is an enjoyable game for Beckett with puns and sarcasm without paying any attention to the metaphysical messages. His sentences are short and quick. And he evades preparing or creating stories; he rather leaves the stories unfinished. The protagonists scoff and laugh at themselves maybe to kill the "time" and life, or habit. As Gontarski and Uhlmann put it "The Beckettian aporia is seen in time as oxymoronic; the image is the ruin of an image and so an afterimage" (8). They are condemned to write, as if it is the only way of escaping the pain of life. Therefore, the symbols are accidental in the story. When "Moran" becomes Beckett, it shows the journey of writer in searching his status of existence by two different ways, and the method cannot be seen in any other predecessors of Beckett, unless partially.

\subsection{Malone Dies}

The narrator is an octogenarian, who constantly talks about his unproductivity. Like "Molloy" and "Moran", he does not know how he gets to the room he is confined in. He has a "stick" by his bed and a vague memory of a forest and an ambiguous thought about a fight with an unknown person. "But perhaps I was stunned with a blow, on the head, in a forest perhaps, yes now that I speak of a forest I vaguely remember a forest" ("Trilogy" 184). He may be "A" or "C" in "Molloy" or the man that "Moran" beats. But, as previously stated, Beckett leaves the stories without any clues as he is not interested in telling an integrated story. The only continuity of the book is the death of "Malone". He reclines in his bed with a lot of difficulty and pain. He searches through his stuffs around his bed with 


\section{Dr. Hossein Sabouri et al.}

his "stick". "My possessions are in a corner, in a little heap. With my long stick I can rummage in them, draw them to me, send them back ("Trilogy" 184). His other needs are basic and rudimentary. In addition, he writes; writing is his only hobby and method to kill the "time" in the way towards death. He writes about a teenager named "Saposcat". The teenager lives near the house of a harsh and fretful man named "Lambert" or the "Big Lambert". "The Lamberts. The Lamberts found it difficult to live, I mean to make ends meet" ("Trilogy" 199). But the story makes "Malone" bored. So, he turns to the story of "Macmann". "Macmann" is a tramp, who is collapsing in the chaos of the modern city. Then, he moves to an asylum as the name of "House of St. John of God". "They said in substance, You are now in the House of Saint John of God, with the number one hundred and sixty-six" ("Trilogy" 257). In the asylum, he receives the nursing and sympathy of "Moll". "Who are you? said the speaker. Someone replied, But it is Moll, can't you see, her name is Moll" ("Trilogy" 258). Then, he has a cold and dark intercourse with "Moll" in spite of his "sterility". "And in the pleasure he was later to enjoy, when he put his tongue in her mouth and let it wander over her gums, this rotten crucifix had assuredly its part. But from these harmless aids what love is free?" ("Trilogy" 265). However, very suddenly, "Moll" dies and leaves his beloved "Macmann" to "Lemuel" to be looked after. "Lemuel" is the new male nurse that uses a "stick" to reach things and suffers from sadistic behaviors. Near the end of the novel, the gracious and generous "Lady Pedal" takes "Lemuel" and his patients, including "Macmann" to a picnic in an island. Getting there, "Lemuel" loses his mind and kills two accompanies, "Maurice" and "Ernest", with a "hatchet". "Lemuel released Macmann, went up behind Maurice who was sitting on a stone filling his pipe and killed him with the hatchet" ("Trilogy" 288). When Lemuel and his lunatic fellows are in the boat, the novel finishes with the end or the "death" of "Lemuel", "Macmann", and their creator, "Malone". At the end of the novel, Beckett gains a unique style of his own, which is bare and flexible. The statements of the novel are only a literary piety and preciseness. The boundary between the form and content is eliminated in the novel. "[H] insists upon the union of form and content" (Cohn 19-20). The narrator attempts and struggles to collapse into his nothingness. As the boat goes into the darkness little by little, "Malone" dies slowly too. The penalty of being alive has come to an end, as "Malone" is a felon in the punishment. His pen is the same as "hatchet", "stick", and "fist" ("Trilogy" 289). The style is so fluent and the content, at the end of the novel, reaches a solace, which is rooted in the nihilistic aesthetics. He demolishes the traditional and avant-garde novels to open his way towards a new type of novel; "meta-textual":

[T]here is . . . a voice resembling, to the point of their being mistaken for one another, the critical voice . . . Few, very few readers succeed in refusing a full and complete legitimacy to this metatextual voice of Beckett's texts, which denies them any pretension to stating the truth about the work in question. (Connor 172)

Beckett seeks "sterility" in his works; he deforms his novels and exposes them to bareness, i.e. the protagonists, and setting lose their forms to be vague, unclear, ambiguous, and "sterile" to show that Beckett escapes from enhancing and giving life to his characters.

\subsection{The Unnamable}

The "Unnamable", unlike "Malone Dies", does not contain anything such as plot, story, or characters. As it turns out, Beckett's pessimism is deeper than what has been perceived, as he does not allow "death" to be the end. The voices and whispers can be heard beyond the grave, beyond the purgatory; what is called the "unnamable". The name precisely describes the vague and indeterminate nature of the book. The novel is a "monologue" narrated by a primitive animal from the underworld; a protobeing. Although he feels the pain in his knees and hands, he has no formal or concrete feature in his face (such as he does not have a "nose"), as well as an inactive body without "sexual organ", which is unable to move; "But the days of sticks are over, here I can count on my body alone, my body incapable of the smallest movement and whose very eyes can no longer close as they once could" ("Trilogy" 303). Nevertheless, he writes; however, the process is unknown and he does not ponder on it. He watches with crying and red eyes. "In a sense I would be better off at the circumference, since my eyes are always fixed in the same direction" ("Trilogy" 297). The status is so dark and there is no sign except for the "mortal liveliness" ("Trilogy" 294) of "Malone". He has no past. He has been there and he "shall not be alone, in the beginning" ("Trilogy" 294). He has actually no information about his "mother", birthplace, and "God"; the information are either forgotten or ignored. He achieves an existence after death; a hell. His torture in the hell is to "write". He writes or speaks to exonerate him from the need and guilt of "writing". He demands to speak about himself or as he calls it, "I". But 
who is the "I". "I, of whom I know nothing" ("Trilogy" 306). From this point on the paragraph continues for more than 100 pages to be stopped. He also tells the story of "Mahood", who lives in a "jar" outside of a "restaurant" without specific details. "Stuck like a sheaf of flowers in a deep jar, its neck flush with my mouth, on the side of a quiet street near the shambles, I am at rest at last" ("Trilogy 329"). The only content in the "Unnamable" is the "words" and unbearable need to use them. However, as the novel continues, the "words" even lose their relationship with the reality. The sentences become more disjoint and dispersed quickly until nothing remains but the ambiguous sense of subjective presence filled with terror and nausea. Maybe the tone of the last part is promising and pessimistic, but after reading more than a one-hundred-page paragraph, the only affirmation is "exhaustion", even for the scholarly readers. The pains and tortures of a man, who is condemned in an eternal punishment for unknown reasons, cannot be ignored; he is in the hell of "words". The statement of the torture is a paradox as by increasing the torture, the verbiage extends. "[T]he situation of him who is helpless, cannot act, in the end cannot write, since he is obliged to write; the act of him who, helpless, unable to act, acts, in the end writes, since he is obliged to write" (Kenner 201). The main issue of the "trilogy" is not to accept melancholy or to go beyond it, but on the contrary, it introduces the Beckett's struggle to complete an artistic form in order to be dead, at least figuratively. "Death" is not only the content of Beckett's works, but also is their form or literary creativity. As Davies affirms, "again we can see that although traditional forms of tragedy would steer our awareness towards death simply owing to the subject matter, Beckett shows a more involved interest in the meaning of the death process and the death force itself" (33). All the humanistic details are stripped away until nothing is remained except for the equivalent aesthetics: a kind of "moribund" artistic form that is bared to nothing except for the primary supposition, i.e. literature or language. In fact,"Beckett remained true, to the end, to the moribund language and literature undoubtedly helping to animate his writing" (Barfield, et al. 17).

\section{THE SCHOOL AND BECKETT}

Talking about the concept of atmosphere, Adorno mentions the "bareness" and emptiness of style in the works of Beckett. "Even in Beckett ... all concrete historical elements seem to have been eliminated and only primitive situations and modes of behavior are tolerated" (Adorno, "Notes to Literature" 225-6). What he means is that primitivism is the ultimate step of "regression". "The primitivism which is the abrupt point of departure for his works reveals itself to be the final phase of a regression" (Adorno, "Notes to Literature" 226). He confesses that what Beckett indicates in his works is the "thematic" representation of Horkheimer and Adorno's model. "He makes thematic something that Horkheimer and I, in the Dialectic of Enlightenment, called the convergence between a society totally in the grips of the culture industry and the reactions of an amphibian" (Adorno, "Notes to Literature" 226). However, Adorno's sharp consideration of Beckett happens in his article "Trying to Understand Endgame" (1958) in the first volume of "Notes to Literature". For Adorno, Beckett's oeuvre is rooted in the "French Existentialism". But his existentialism is different due to his form or style. "But whereas in Sartre the form - that of the pièce á thèse - is somewhat traditional, by no means daring, and aimed at effect, in Beckett the form overtakes what is expressed and changes it" (Adorno, "Notes to Literature" 241). Adorno perceives Beckett's "Existentialism" as non-conformity. Accordingly, Beckett's works destroy the rudiments of culture and thus are against the bourgeois. "In Beckett, this kind of objectivity annihilates the meaning that culture once was, along with its rudiments. And so culture begins to fluoresce" (Adorno, "Notes to Literature" 241-2). He asserts that philosophy or "spirit" is dead and the process is "wastage". "[P]hilosophy, spirit itself, declares itself to be dead inventory, the dreamlike leavings of the world of experience, and the poetic process declares itself to be a process of wastage" (Adorno, "Notes to Literature" 243). And he conveys that Beckett is rightfully against philosophy or "systematic thinking", which is against the bourgeois values. "Beckett shrugs his shoulders at the possibility of philosophy today, at the very possibility of theory" (Adorno, "Notes to Literature" 244). In Kafka meaning is "disheveled", Adorno argues, but Beckett changes the meaning into being "meaninglessness", which later on transfers to "absurdity". Marcuse believed that the aesthetics can be free from one dimension and helps the writer to call other dimensions, and he finds the aesthetics in the novels of Beckett. "The aesthetic dimension still retains a freedom of expression which enables the writer and artist to call men and things by their name - to name the otherwise unnameable. The real face of our time shows in Samuel Beckett's novels" (Marcuse 251). Fredric Jameson discusses Adorno's view on political art; he argues that the political art has leaned towards the notion of "autonomous art" and Adorno is the one who considers the 


\section{Dr. Hossein Sabouri et al.}

"revolutionary artist" of the time no one except Samuel Beckett. Jameson believes that Adorno sees "the classical stage of high modernism itself as the very prototype of the most 'genuinely' political art ... and his suggestion ... is Beckett who is the most truly revolutionary artist of our time" (Adorno, et al. 209). Furthermore, along with the view of Jameson, Adorno talks about "the true relation of art to reality" that he finds in Beckett. He believes that the "avant-garde" art is against the domination of bourgeois value; but not all the "avant-garde" movements. "This could be shown in Beckett's works. These enjoy what is today the only form of respectable fame: everyone shudders at them, and yet noone can persuade himself that these eccentric plays and novels are not about what everyone knows but no one will admit" (Adorno, et al. 190). He challenges "philosophical apologists" of seeing Beckett's works as an anthropological approach and calls for a deeper look in his oeuvre, which can show the "abdication of the subject" and the historical reality beyond a symbolic face. "[T] hey deal with a highly concrete historical reality: the abdication of the subject. Beckett's Ecce Homo is what human beings have become. As though with eyes drained of tears, they stare silently out of his sentences" (Adorno, et al. 190).

\section{The Trilogy: New Notions and A Solution to Modern Man’s Problems}

One of the Beckett's solutions for the dichotomy of subject-object is a "chain" of subjects and objects that merge into one another. He shows how the son, "Molloy" becomes the "mother", or the object. Then, as a "mother" the narrator talks about her son:

I have taken her place. I must resemble her more and more. All I need now is a son. Perhaps I have one somewhere. But I think not. He would be old now, nearly as old as myself. It was a little chambermaid. It wasn't true love. The true love was in another. We'll come to that. Her name? I've forgotten it again. It seems to me sometimes that I even knew my son, that I helped him. ("Trilogy" 8)

Here, one cannot observe any difference between the subject and its object as if they are united to be one notion. Another great example would be the end of "Malone Dies". "Lamuel", the object of the writing, gets united with the subject or author, i.e. "Malone":

Lemuel is in charge, he raises his hatchet on which the, blood will never dry, but not to hit anyone, he will not hit anyone, he will not hit anyone any more, he will not touch anyone any more, either with it or with it or with it or with or

or with it or with his hammer or with his stick or with his fist or in thought in dream I mean never he will never

or with his pencil or with his stick or

or light light I mean

never there he will never

never anything

there

any more ("Trilogy" 289)

But this is not the end of it. "Malone" interrupts the other parts of "the trilogy" in a way that he presents another form of reality of subject-object world. This explanation of "Malone" happens to explain that part of "Molloy" that "Moran" kills a man and buries him. "I do not know what happened then. But a little later, perhaps a long time later, I found him stretched on the ground, his head in a pulp. I am sorry I cannot indicate more clearly how this result was obtained" ("Trilogy" 152). Again, the object shifts into being the subject and "the trilogy" constantly blurs the distinction between both notions.

The other notion in "the trilogy" indicates how the characters avoid "submission" in all senses. All of the protagonists, i.e. "Molloy", "Moran", "Malone", and even the "Unnamable", continuously write. They are condemned to "write" interminably forever and ever. References to writing are numerous, such as on page 133, "But I write them all the same, and with a firm hand weaving inexorably back and forth and devouring my page with the indifference of a shuttle" ("Trilogy" 133). Or,"I would gladly describe it, I would gladly write four thousand words on it alone" ("Trilogy" 155). In another section of the trilogy it states, "I did not want to write, but I had to resign myself to it in the end. It is 
in order to know where I have got to, where he has got to. At first I did not write, I just said the thing" ("Trilogy" 207-8). Or, "So I write as lightly as I can. But the lead is hard and would leave no trace if I wrote too lightly" ("Trilogy" 223). As another example, it can refer to page 303, "It is I who write, who cannot raise my hand from my knee. It is I who think, just enough to write" ("Trilogy" 303). They write inexorably and relentlessly, even when they feel the "pain" and "fatigue" of "writing". They do not yield or "submit" because they think that the true death is to stop "writing" and it is inevitable. Surprisingly, even after the death of "Malone", the "writing" is not deceased. The fight against "submission" continues through other actions and devices. The characters of "the trilogy" start and continue their journey without stopping by any means. Although both "Molloy" and "Moran" are crippled and lost their energy, they go on using "bicycles" and "crutches" in a way that they are the inseparable parts of their body. "I have crutches now. I shall go faster, all will go faster" ("Trilogy" 16). However, when there are not even bicycles and crutches, they continue by "crawling", and even on their hands and knees. "There is crawling I never thought of that" ("Trilogy" 89). "Moran" also "crawls": "I crawled out in the evening to have good laugh" ("Trilogy" 163); just like "Malone". "There is virtually nothing it can do. Sometimes I miss not being able to crawl around anymore" ("Trilogy" 186). The same is true for the "Unnamable" to "crawl out again" ("Trilogy" 399). The protagonists struggle against being "powerlessness", as they find it a phenomenon that shapes them into "commodities". Beckett knows that "submission" and "powerlessness" lead to the "reification" of his characters to be encompassed by the mechanism of the "Capitalism"; therefore, he gives them a power to continue, even after death, constantly.

Therefore, the explanation leads to another solution of Beckett for the modern man's problems, which is the elimination of "collective/ mass medium". The protagonists are aloof writers, who show mere individuality. The pariahs are hated by the society. They even cannot answer a simple question posed by the society. "I knew I was bound to be stopped by the first policeman and asked what I was doing, a question to which I have never been able to find the correct reply" ("Trilogy" 60).

But this is not the matter of society in rejecting them, but also they cannot tolerate the presence of the society's members. "Molloy" could not stand the mercy and kindness of the dog owner and thus he escapes. The act of "writing" is also important because it is the only individualistic need of the protagonists. In his book, "Samuel Beckett: A Critical Study", Hugh Kenner argues that the solitary act of writing "the trilogy" is an attempt to hit the decadent structure of the dichotomy:

The marks of this are perfectly clear in The Unnamable, the protagonist of which knows that he thinks but would like to feel certain that he exists, as well as in Molloy, where the body (at first hardly distinguishable from a bicycle) is as clearly a machine as Descartes established it was, though here a machine subject to loss and decay. This Cartesian focus is something more than a pedantic coincidence. (17)

But to resolve the dichotomy, Beckett suggests a type of writing, which "Malone" exploits to devastate the boundary between the subject and object, and to unite them to be one. Beckett seems to be an "absurd" writer by many, which can be true to some extent; however, he transcends the notion. According to Badiou, in his book "On Beckett", Beckett is a modern writer, who transcends realism and he exploits a type of writing that is both a story and the reality:

But also a 'modern' writer, in that the destiny of writing, the relationship between the endless recapitulation of speech and the original silence - the simultaneously sublime and derisory function of words - was entirely captured by the prose at a distant remove from any realist or representational intention. In such 'modern' writing, fiction is both the appearance of a story and the reality of a reflection on the work of the writer, on its misery and its grandeur. (38)

\section{CONClusion}

The study employed a descriptive-analytical method through a textual analysis and is qualitative. For the descriptive part, the theories and ideas of the Frankfurt School were explained, whether through mentioning their ideas directly or through the ideas of other critics. Furthermore, a textual analysis of "the trilogy" of Beckett was discussed and details were provided out of their texts. The study claimed the liberating role of "the trilogy" in answering and providing solutions for the modern man's problems. The overall analysis of the study suggested that "the trilogy" of Beckett can provide solutions for those modern man's problems that have been raised by the First Generation of the Frankfurt School. 


\section{REFERENCES}

Adorno, T. "Negative Dialectics.” Taylor \& Francis, 2003. Print.

Adorno, T.W., and E.F.N. Jephcott. “Minima Moralia: Reflections on a Damaged Life.” Verso, 2005. Print.

Adorno, T.W. "The Jargon of Authenticity." Northwestern University Press, 1973. Print.

Adorno, T.W., et al. "Notes to Literature." New York: Columbia University Press, 1993. Print.

---. "Notes to Literature." New York: Columbia University Press, 1993. Print.

Badiou, A., N. Power, and A. Toscano. "On Beckett." Clinamen, 2003. Print.

Barfield, S., M. Feldman, and P. Tew. "Beckett and Death." Bloomsbury Publishing, 2011. Print.

Beckett, Samuel. Trilogy: Molloy, Malone Dies, The Unnamable. London: Calder Publication, 1994. Print.

Bellini, F. "He tolle'd and Legge'd: Samuel Beckett and St. Augustine, Habit and Identity in Dream of Fair to Middling Women and Murphy." Lingue e Linguaggi, vol. 13, 2015, pp. 23-24.

Benjamin, W. "Illuminations". Houghton Mifflin Harcourt, 1968. Print.

Chesca, A. B. "The Literature of the Absurd: Writing against Death." ACTA Universitatis Danubius, vol. 7, no. 1, 2013, pp. 93-98.

Cohn, R. “A Beckett Canon.” University of Michigan Press, 2001. Print.

Connor, S. "Beckett, Modernism and the Material Imagination." Cambridge University Press, 2014. Print.

Davies, P. "Beckett and Eros: Death of Humanism." Palgrave Macmillan UK, 2000. Print.

Freud, S. "Civilization and Its Discontents." 1962. Print.

Horkheimer, M., T.W. Adorno, and G. Noeri. "Dialectic of Enlightenment." Stanford University Press, 2002. Print.

Jamalinesari, A., Feilinezhad, N. "Mental Self-Exploration in Samuel Beckett's Molloy: A Jungian Approach." Advances in Language and Literary Studies, vol. 6, no. 1, Feb. 2015, pp. 11-15, doi:10.7575/aiac.alls.v.6n.1p.11.

Jay, M. "The Dialectical Imagination: A History of the Frankfurt School and the Institute of Social Research." 1923-1950. University of California Press, 1973. Print.

Kenner, H. “A Reader's Guide to Samuel Beckett.” New York: Syracuse University Press, 1996. Print.

Lansdown, R. "The Autonomy of Literature." Palgrave Macmillan UK, 2001. Print.

---. "Samuel Beckett, a Critical Study." California: University of California Press, 1968. Print.

Lopez, J. M. "Samuel Beckett's Trilogy, Alain Badiou and the Substraction from the State and the Community." Estudios Irlandeses, Nov. 2013, pp. 32-42.

Marx, K., et al. "Capital Vol 1." Penguin Books Limited, 1990. Print.

Marcuse, H. "One-Dimensional Man: Studies in the Ideology of Advanced Industrial Society." Taylor \& Francis, 2013. Print.

Meihuizen, N. C. T. "Beckett and Coetzee: alternative identities. ” Literator, vol. 32, no. 1, Mar. 2011, pp. all.

Najafi, A., Ghasemi, P., Pourgiv, F. "Failed Quest in Samuel Beckett's How It Is." International Journal of Applied Linguistics \& English Literature, vol. 1, no. 6, Nov. 2012, pp. 247-253, doi:10.7575/ijalel.v.1n6p.247.

Nietzsche, F.W., and T. Wayne. "Ecce Homo: How One Becomes What One Is; the Antichrist: A Curse on Christianity.” Algora Pub., 2004. Print.

Nietzsche, F., R. Geuss, and R. Speirs. "Nietzsche: The Birth of Tragedy and Other Writings." Cambridge University Press, 1999. Print.

Sasani, S., Ghasemi, P. "The Influence of Anton Chekhov on Samuel Beckett: Inaction and Investment of Hope into Godot-like Figures in Three Sisters and Waiting for Godot." Kata, vol. 13, no. 2, Dec. 2011, pp. 221-235.

Shalghin, A. "Time, Waiting, and Entrapment in Samuel Beckett." International Journal of Humanities and Social Science, vol. 4, no. 9, Jul. 2014, pp. 101-117.

Uhlmann, A. "Beckett After Beckett." University Press of Florida, 2006. Print.

Wilson, R. "Theodor Adorno." Taylor \& Francis, 2007. Print. 


\section{AUTHORS' BIOGRAPHY}

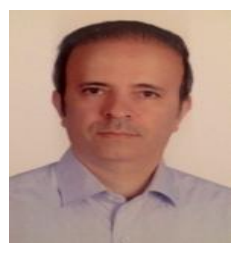

Dr. Hossein Sabouri, Associate Professor, University of Tabriz

He received his $\mathrm{PhD}$ in English Literature and Language from Punjab University Chandigarh. He has been teaching English Literature and Language in University of Tabriz since 2004. He published many articles and books including English Poetry: From Renaissance to T. S. Eliot.

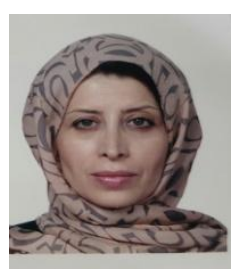

Dr. Firouzeh Ameri, Assistant Professor, University of Tabriz

She joined The University of Tabriz in 2011 after receiving her PhD in English and Comparative Literature from Murdoch University, Australia. Since joining that university, she has been teaching BA and MA courses of English literature and doing research related to narrative fiction, postcolonial studies and women's studies. She is now an assistant professor in the Faculty of Persian Literature and Foreign Languages of the University of Tabriz.

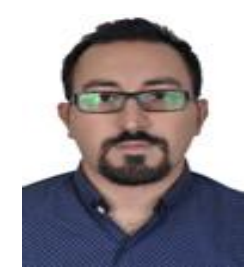

Sobhan Jahangiri, M. A. Student, University of Tabriz

He finished his B. A. in English Literature and Language in University of Guilan. He co-authored some articles in various fields of study including English Literature and Consulting. 